\title{
Immunohistochemical aspects of insulin-like growth factors I and II in the bovine corpus luteum
}

\author{
W. Amselgruber ${ }^{1}$, F. Sinowatz ${ }^{1}$, D. Schams ${ }^{2 *}$ and A. Skottner ${ }^{3}$ \\ ${ }^{1}$ Institute of Veterinary Anatomy II, Histology and Embryology, University of Munich, Munich, \\ Germany; ${ }^{2}$ Institute of Physiology. Technical University of Munich-Freising-Weihenstephan, Germany; \\ and ${ }^{3}$ Kabi Biopharma, Peptide Hormones, S-112 87 Stockholm, Sweden
}

\begin{abstract}
The cellular distribution of insulin-like growth factors I and II (IGF-I and -II) was examined in bovine corpora lutea at different stages of the luteal phase using specific antibodies and the avidin-biotin immunoperoxidase technique. At the cellular level, intense immunostaining for IGF-I was exclusively observed in large and small luteal cells and in a limited number of endothelial cells. Positive IGF-I immunoreactivity in luteal cells was thereby distributed in a distinct topographical, lobule-specific manner. Immunoreactivity in central areas of luteal lobules was most abundant in large luteal cells, whereas in peripheral zones significantly $(P<0.05)$ more small luteal cells exhibited IGF-I immunoreactivity. This distribution pattern was evident from day 4 of the cycle onwards and occurred at all the stages investigated. The percentage of positive small (SLC) and large (LLC) luteal cells revealed by semiquantitative analysis depended on the stage of the cycle as follows: days 4-7: $34 \%$ LLC versus $21.3 \%$ SLC in central areas and $25.1 \%$ LLC versus $32.7 \%$ SLC in peripheral zones; days 8-12: $42.9 \%$ LLC versus $19.9 \%$ SLC in central areas and $23.5 \%$ LLC versus $35.2 \%$ SLC in peripheral zones; days $13-16: 47.7 \%$ LLC versus $19.4 \%$ SLC in central areas and $19.2 \%$ LLC versus $41.4 \%$ SLC in peripheral zones. In contrast to IGF-I, no expression of IGF-II immunoreactivity was seen in large or small luteal cells. Positive immunoreactivity was restricted to the perivascular fibroblasts of large blood vessels and to the pericytes of capillaries. Fibroblasts, which are located in the fine interlobular connective tissue, also exhibited strong immunoreactivity for IGF-II, whereas endothelial cells were not stained. Semiquantitative evaluation was not possible owing to the low number of positive cells compared with the total number of cells. The restriction of strong IGF-II immunoreactivity to the pericytes of capillaries and to the perivascular fibroblasts of arterioles and venules supports the hypothesis that IGF-II acts as an autocrine growth factor, affecting the proliferation and differentiation of these cells.
\end{abstract}

\section{Introduction}

Development of the corpus luteum proceeds via a complex sequence of interactions between luteal cells, vascular cells and connective tissue components, and involves cellular growth and differentiation. These interactions are mediated principally by the trophic hormones FSH and LH and by the actions of intraovarian peptides (reviewed by Schams, 1987). In addition, the importance of polypeptide growth factors in the local regulation of ovarian function has become increasingly evident, such that the control of folliculogenesis and luteinization is no longer ascribed solely to endocrine mechanisms, but has been extended to include paracrine and autocrine mechanisms (Adashi $e$ al., 1985a; Hammond et al., 1991). Of the wide array of growth factors, insulin-like growth factors I and II (IGF-I and -II), in particular, are probably involved in the complex

* Correspondence.

Revised manuscript received 30 December 1993. interactions between types of ovarian cell. The granulosa cells of several species are known to produce (Hammond et al., 1985; Oliver et al., 1989; Adashi et al., 1990; Hernandez et al., 1990a; Spicer et al., 1993), have receptors for (Davoren et al., 1986; Adashi et al., 1988a, b, 1990) and respond to (Adashi et al., 1988b; Holtorf et al., 1989; McArdle and Holtorf, 1989) IGF-I. Studies have indicated that IGFs stimulate steroidogenesis and the synthesis of oxytocin and its secretion from follicles and luteal tissue during the oestrous cycle (Baranao and Hammond, 1984; Schams et al., 1988; Holtorf et al., 1989; McArdle and Holtorf, 1989; Sauerwein et al., 1992). Moreover, IGF-I stimulates granulosa cell proliferation and differentiation (Baranao and Hammond, 1984; Adashi et al., 1985a, 1990; Hammond and English, 1987; May et al., 1988; Schams et al., 1988; Olsson et al., 1990); in particular it enhances FSH-mediated progestin secretion (Adashi et al., 1985b; Veldhuis and Demers, 1985; Veldhuis et al., 1986; Monniaux and Pisselet, 1992), aromatase activity (Adashi et al., 1985b; Steinkampf et al., 1988) and induction of LH receptors (Adashi et al., 1985a). 
Einspanier et al. (1990) recently reported the expression of IGF-I mRNA in bovine luteal tissue during the oestrous cycle and gestation, which correlated with increasing IGF-I concentrations in luteal tissue. As in other species (Hsueh et al., 1984; Adashi et al., 1985a; Parmer et al., 1991), these studies support a regulatory role for IGF-I in granulosa-luteal cell development in cows, even though the cellular production site of IGF-I within the ovary was not identified.

Despite extensive studies on the role of IGF-I in ovarian function, little attention has been paid to IGF-II. This growth factor is considered to play an important role in fetal growth and development, and the gene expression is tissue specific and developmentally regulated. IGF-II has been shown to stimulate cell division, modulate differentiation of granulosa cells (Baranao and Hammond, 1984; Davoren et al., 1986; Adashi et al., 1990; Erickson et al., 1990) and to promote androgen production by the thecal interstitial cells of the ovary. Moreover, Hernandez et al. (1990b) have convincingly demonstrated that IGF-II gene expression and transcripts in rat ovarian tissue are specific to theca-interstitial cells, although the exact type of cell showing IGF-II transcripts could not be determined. In the present study immunocytochemistry was used to determine the types of IGF-I and IGF-II positive cells during various stages of the bovine corpus luteum.

\section{Materials and Methods}

\section{Tissue collection and fixation}

Fifteen corpora lutea, used in this study, were collected from normal cyclic heifers of the German Simmental (Fleckvieh) breed immediately after death at a local abattoir. The stage of the cycle was determined by examination of the ovaries (follicles and corpora lutea) and uterus (size, colour, consistency and mucus), and confirmed by histology (Höflinger, 1948). The corpora lutea were divided into four groups (at least three different animals per group) corresponding to the following days of the cycle: $1-3,4-7,8-12$ and $13-16$ (day $1=$ day of ovulation). The tissue was initially perfusion-fixed, then postfixed by immersion in fixative. Specifically, the arteria ovarica was cannulated immediately after death and the vascular system of the ovary prerinsed with physiological saline. Perfusion-fixation with Bouin's solution for $5 \mathrm{~min}$ followed. The ovaries were then dissected into $0.5 \mathrm{~cm}$ thick tissue slices, post-fixed in Bouin's solution for $6 \mathrm{~h}$, dehydrated in a graded series of ethanol, cleared in xylene and embedded in paraffin wax using conventional procedures. Three to four different corpora lutea were analysed per stage. Sixty serial sections of 4-6 $\mu \mathrm{m}$ thickness per corpus luteum were cut on a Leitz microtome and every twentieth section was subjected to immunohistochemical testing using antibodies to IGF-I and IGF-II.

\section{Immunohistochemistry}

The polyclonal antibody to IGF-I (K 1801: Kabi Pharmacia, Stockholm) was directed to the carboxy-terminal portion and showed no crossreactivity in a radioimmunoassay $(<1 \%$ with IGF-II, insulin or other related peptides). IGF-II immuno- reactivity was demonstrated using a monoclonal antibody purified from mouse ascites (MAS 324: Amano Corp., Tokyo). Crossreactivity was $<0.1 \%$ for human IGF-I and bovine insulin.

Antigen localization was achieved using the avidin-biotin immunoperoxidase technique. After deparaffination and rehydration, potential endogenous peroxide activity was suppressed by incubation with methanolic hydrogen peroxide. The sections were placed in a moist chamber and covered initially with normal goat serum (diluted 1:10) for 30 min to minimize nonspecific staining. Overnight incubation at $4^{\circ} \mathrm{C}$ with $1: 1000$ dilutions of either rabbit anti-IGF-I or mouse anti-IGF-II IgG (10 $\mathrm{ng} \mathrm{ml}{ }^{-1}$ ) followed. After washing in PBS (1.4\% NaCl, $0.28 \% \mathrm{Na}_{2} \mathrm{HPO}_{4}, 0.08 \% \mathrm{KH}_{2} \mathrm{PO}_{4}, \mathrm{pH} 7.2$ ), the sections were incubated for $30 \mathrm{~min}$ with biotinylated goat anti-rabbit IgG (IGF-I) or with goat anti-mouse IgG (IGF-II). The sections were then reacted with avidin-biotin-peroxidase reagent from a commercial kit (Vector Laboratories, Burlingame, CA). The bound complex was made visible by reaction with $0.05 \%$ $3,3^{\prime}$-diaminobenzidine hydrochloride and $0.0006 \% \mathrm{H}_{2} \mathrm{O}_{2}$ in $0.1 \mathrm{~mol} \mathrm{PBS} \mathrm{I}^{-1}$

The specificity of the immunocytochemical reactions was assessed on the basis of absorption tests involving the respective antigens (15 $\mu \mathrm{g} \mathrm{ml}^{-1}$ recombinant human IGF-I or IGF-II; Ciba Geigy, Basle). Specificity of the staining reaction was further substantiated by serial dilution of the primary antigen, which resulted in a gradual decrease in intensity and, finally, in the lack of staining. Further controls included: (i) replacement of the primary antibodies with buffer; (ii) their substitution with non-immune, protein A-sepharose-purified goat IgG (diluted 1:10) and (iii) incubation with diaminobenzidine reagent alone to exclude the possibility of non-suppressed endogenous peroxidase activity. Lack of detectable staining of tissue elements in the controls demonstrated the specificity of the reactions.

\section{Evaluation of the percentage of positive cells}

The percentages of IGF-I positive large and small luteal cells were determined by counting the positive and negative staining cells of a total number of 1000 cells per area. Nonoverlapping areas were chosen at random from four central and four peripheral parts. Three sections of three to four different animals per stage were analysed. Assessment of cell counting was performed at a magnification of $\times 500$.

\section{Statistical analysis}

The data from immunoscreening were analysed by ANOVA. When ANOVA showed significant differences, the Bonferoni test (Snedecor and Lochran, 1982) was used to test the significance.

\section{Results}

\section{Insulin-like growth factor I}

Positive staining for IGF-I was observed in all of the luteal stages investigated (Fig. 1). The presence of IGF-I was 

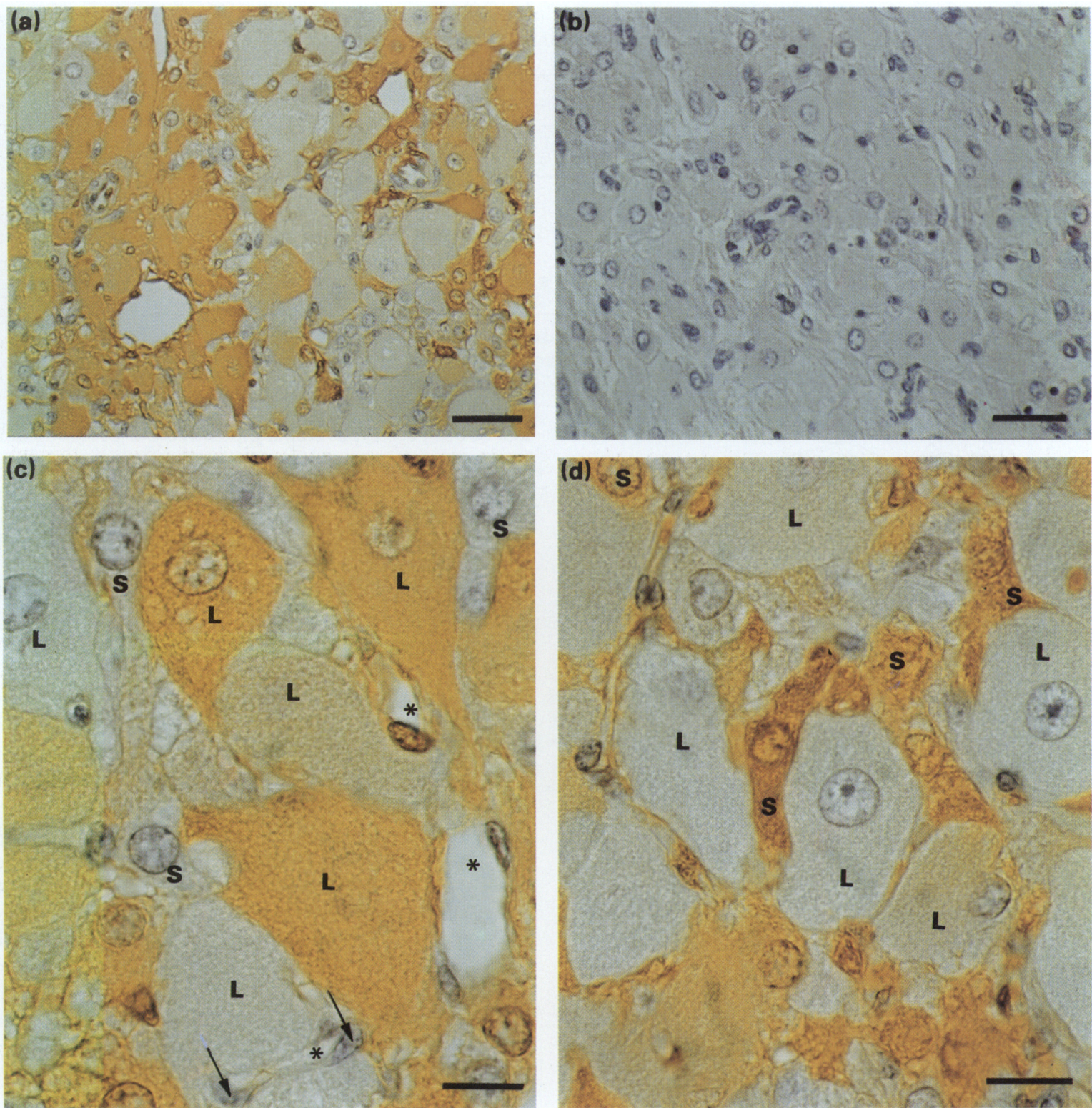

Fig. 1. Insulin-like growth factor I (IGF-1) immunoreaction in bovine luteal tissue counterstained with haematoxylin. (a) Central area of a luteal lobule from a mid-luteal phase corpus luteum (days 8-12 of the cycle) incubated with anti-IGF-I antiserum. A strong immunoreaction is seen in luteal cells. Considerable differences in immunostaining were found between neighbouring cells, possibly reflecting different stages of cellular activity. Note that groups of immunopositive large luteal cells are concentrated around postcapillary venules. Scale bar represents $50 \mu \mathrm{m}$. (b) Mid-luteal phase corpus luteum stained with control antiserum. Preabsorption of the IGF-I antiserum with $15 \mu \mathrm{g}$ recombinant human IGF-I $\mathrm{ml}^{-1}$ completely abolished staining of luteal cells. The polyclonal antiserum preabsorbed with IGF-I ( $15 \mu \mathrm{g} \mathrm{ml}^{-1}$ ) was used as control serum. No immunostaining is present. Scale bar represents $50 \mu \mathrm{m}$. (c) High magnification of the central area of a luteal lobule from a corpus luteum (day 4-7) showing IGF-I in large luteal cells. There are differences in the intensity of immunostaining between neighbouring large (granulosa) luteal cells (L) and an absence of staining in small (thecal) luteal cells (S). Note the positive reaction of some endothelial cells whereas other endothelial cells are not stained (arrows). *: Capillaries. Scale bar represents $20 \mu \mathrm{m}$. (d) Intensive IGF-I immunoreaction of small luteal cells (S) from the peripheral area of a luteal lobule (day 13-16). Neighbouring large luteal cells (L) show weak or no immunoreaction. Scale bar represents $20 \mu \mathrm{m}$.

indicated by a dark reaction product that was found in the cytoplasm of large and small luteal cells. The intensity of immunostaining varied from cell to cell and the number of positive cells was influenced by the stage of the cycle. Small and large luteal cells both exhibited these differences in immunostaining. A positive immune reaction for IGF-I was seen to some extent in the stroma. However, it was confined to a subset of endothelial cells with no discernible immunoreactivity in pericytes, fibroblasts, macrophages or the smooth muscle cells of blood vessels.

A particularly striking phenomenon was found while analysing the topographical distribution of IGF-I positive cells in detail (Table I). The bovine corpus luteum, like that of other species, can be subdivided into individual luteal lobules, made 
Table 1. Percentage (mean \pm SEM) of large and small luteal cells positive for insulin-like growth factor I in the central and peripheral areas of bovine luteal lobules

\begin{tabular}{|c|c|c|c|c|}
\hline \multirow{2}{*}{$\begin{array}{l}\text { Luteal stage } \\
\text { (days) }\end{array}$} & \multicolumn{2}{|c|}{ Central area } & \multicolumn{2}{|c|}{ Peripheral area } \\
\hline & Large luteal cells & Small luteal cells & Large luteal cells & Small luteal cells \\
\hline $1-3$ & \multicolumn{2}{|c|}{$42.1 \pm 19.5$} & \multicolumn{2}{|c|}{$41.5 \pm 12.9$} \\
\hline $4-7$ & $34.0 \pm 12.8^{\mathrm{a} *}$ & $21.3 \pm 10.2$ & $25.1 \pm 12.6^{\mathrm{a}}$ & $32.7 \pm 12.1^{*}$ \\
\hline $8-12$ & $42.9 \pm 14.3^{\mathrm{b} *}$ & $19.9 \pm 7.8$ & $23.5 \pm 9.5^{\mathrm{a}}$ & $35.2 \pm 11.1^{*}$ \\
\hline $13-16$ & $47.7 \pm 16.7^{c *}$ & $19.4 \pm 8.0$ & $19.2 \pm 9.4^{b}$ & $41.4 \pm 9.8^{*}$ \\
\hline
\end{tabular}

Different letters indicate significant differences $(P<0.05)$ between different luteal stages. ${ }^{*}$ Significant differences $(P<0.001)$ between the percentage of large and small luteal cells from central and peripheral areas.

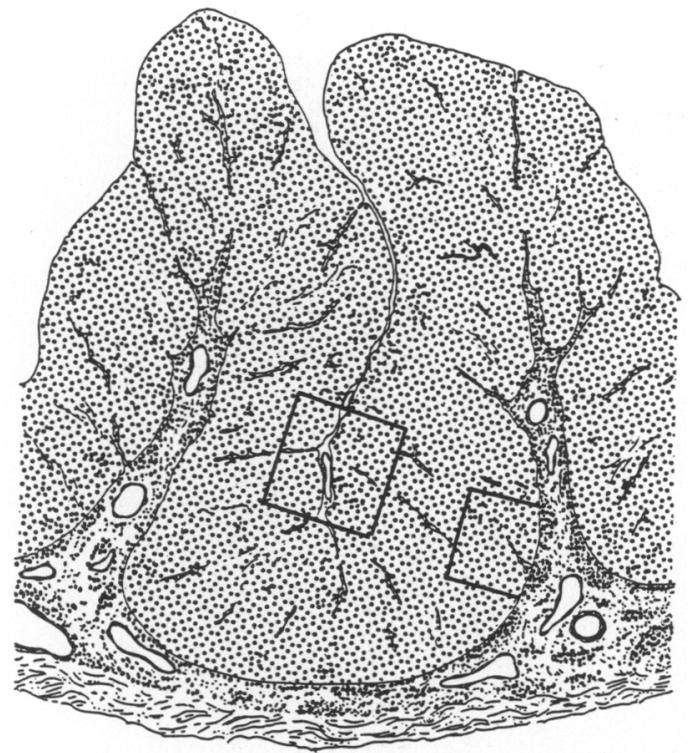

Fig. 2. Schematic drawing of a bovine luteal lobule. Peripheral and central areas are indicated with black rectangles. Cell-type specific insulin-like growth factor I (IGF-I) immunoreactivity depends on topographical localization. In central areas, strong IGF-I immunoreactivity is seen mostly in large luteal cells, whereas in peripheral areas, immunoreactivity is usually restricted to small luteal cells.

up of central and peripheral portions (Fig. 2). In the present investigation, immunoreactivity in the central portions was more abundant in large luteal cells, often arranged around postcapillary venules (Fig. $1 \mathrm{~b}, \mathrm{~d}$ ), whereas in peripheral areas, the positive immunoreaction was more often seen in small luteal cells (Fig. 2e). This distribution pattern was evident from day 4 of the cycle onwards and occurred at all the following stages of the corpus luteum. The results of a semiquantitative evaluation of this aspect were as follows: in the early luteal phase (days 1-3) large and small luteal cells cannot be differentiated. The percentage of all positive cells, independent of their size, was therefore determined for this stage and was $42 \%$ in central areas and $41 \%$ in peripheral areas. In the following stages, more large luteal cells than small luteal cells stained positively in the central areas, whereas in the peripheral zones the number of small luteal cells staining positive predominates over the large cells. The highest percent- age of both cell types staining positive was observed in the late luteal phase (days 13-16) with the same histotopographical localization. The percentages of large and small luteal cells staining positive for IGF-I during the different stages of the luteal phase with regard to the topographical distribution are given (Table 1).

\section{Insulin-like growth factor II}

Contrary to the results obtained with antibodies to IGF-I, no staining for IGF-II was observed in the large and small luteal cells in any of the stages studied. However, a specific positive immunoreaction for IGF-II was seen in certain cell types in the luteal tissue; a particularly strong reaction product occurred regularly in the cytoplasm of a subset of pericytes of capillaries (Fig. 3a, b) and also in perivascular fibroblasts (Fig. 3c). Other fibroblasts, which are located in the fine interlobular connective tissue, also exhibited strong immunoreactivity for IGF-II. No staining was seen in the endothelial cells of large vessels or in the capillaries. No staining was observed in the endothelial cells of the lymphvascular system. In the early luteal phase following ovulation (days $1-3$ ), only a few single cells that stained positively for IGF-II were found, but more positive cells were found in corpora lutea from day 4 onwards.

\section{Discussion}

Several recent reports have suggested that IGF-I and IGF-II are potential factors involved in the local regulation of the ovary and that they could act as regulators of granulosa-theca cell differentiation. Observations by Schams et al. (1988), McArdle and Holtorf (1989) and Sauerwein et al. (1992) suggest that IGF-I affects oxytocin and progesterone release from bovine granulosa and luteal cells. Parallel measurement of IGF-I tissue concentration and mRNA expression in bovine luteal tissue indicated that IGF-I is probably produced by luteal cells (Einspanier et al., 1990).

The present study demonstrates for the first time using immunocytochemistry the cellular, regional and temporal distribution of IGF-I in the bovine corpus luteum during the oestrous cycle. Immunostaining of paraffin sections revealed that IGF-I primarily occurs in large and small luteal cells, indicating that these two cell types are the major source or site 

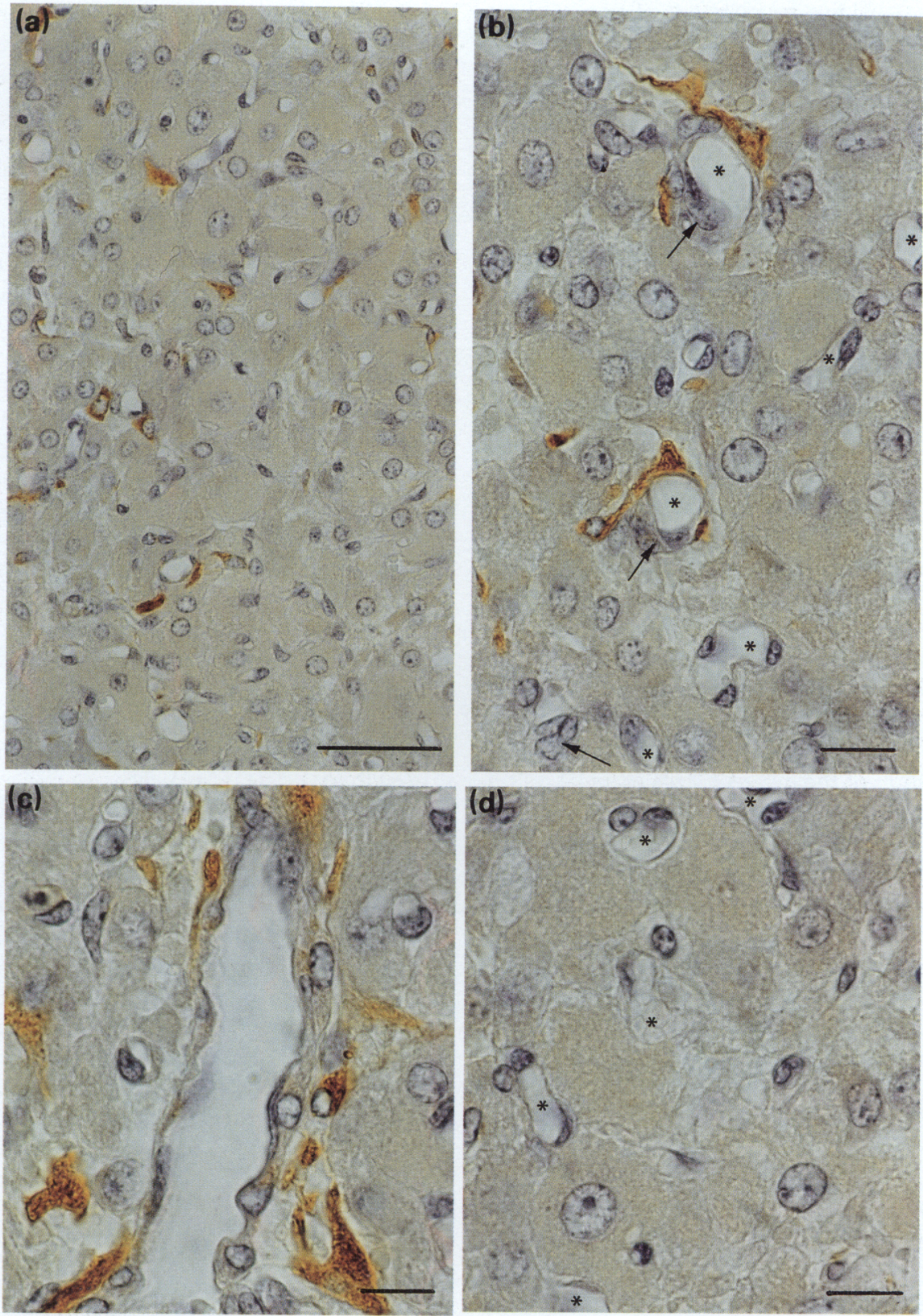

Fig. 3. Insulin-like growth factor II (IGF-II) immunoreaction in bovine luteal tissue using the monoclonal antibody MAS 324 and counterstained with haematoxylin. (a) Positive immunoreaction is restricted to pericytes and fibroblasts and no immunostaining is detectable in large and small luteal cells. No differences regarding the stained cell type were observed between luteal tissue from different stages of the cycle. Scale bar represents $50 \mu \mathrm{m}$. (b) Larger magnification of (a) showing that only a subset of pericytes reveals strong immunoreaction, whereas other pericytes (arrows) remain unstained. No staining was observed in endothelial cells and both types of luteal cells. *: Capillaries. Scale bar represents $20 \mu \mathrm{m}$. (c) Intense immunostaining was also detectable in perivascular fibroblasts (days 8-12). No staining of endothelial cells with the antibody against IGF-II was seen. Scale bar represents $20 \mu \mathrm{m}$. (d) Control section. Preabsorption with recombinant human IGF-II $\left(15 \mu \mathrm{g} \mathrm{ml} \mathrm{ml}^{-1}\right)$ abolishes immunostaining completely. *: Capillaries. Scale bar represents $20 \mu \mathrm{m}$.

of action of intraluteal IGF-I in this species. This interpretation is supported by the fact that no discernible immunoreactivity was seen in pericytes, fibroblasts, macrophages or smooth muscle cells of blood vessels. The pronounced differences in the regional distribution of IGF-I immunoreactivity and the variations between neighbouring cells may reflect different states of specific cellular activity, thereby indicating possible paracrine or autocrine interactions between the large and small 
luteal cells of the corpus luteum of cyclic cows. Another possibility is that regional distribution depends on the proximity of cells to blood vessels since one likely source of immunoreactive IGF-I is blood serum. Our analysis shows that the greatest number of cells positive for IGF-I occurs in the late luteal phase, with the maximum between days 13 and 16. This distribution is in accordance with the results of Einspanier et al. (1990). These authors demonstrated a high correlation between mRNA for IGF-I and immunoreactive IGF-I. Tissue concentrations of IGF-I increased between days 1-5 and days 12-17 of the cycle, followed by a rapid decrease after luteolysis. The typical lobule-dependent regional distribution described in the study reported here may be closely related to the morphogenesis of the luteal lobules, during which granulosa-lutein (that is, large luteal) cells are associated with the central region, whereas the theca-lutein cells are found more frequently in the peripheral regions of the lobule. This histotopographical distribution raises the controversial problem of how often a differentiation from small into large luteal cells and vice versa occurs during the course of the oestrous cycle (reviewed by O'Shea, 1987). The fact that such differentiation of bovine theca and granulosa cells into small and large luteal cells can be triggered by several factors (for example, IGF-I) was recently demonstrated by the studies of Meidan et al. (1990) in vitro. Moreover, Parmer et al. (1991) suggested that IGF-I may be involved in the formation of the different sizes of luteal cells in the rat corpus luteum, and that the larger size of the one cell population may be related to its superior ability to respond to signals provided by growth factors such as IGF-I. Alila and Hansel (1984) hold the view that bovine large luteal cells are derived exclusively from granulosa cells and that small luteal cells stem only from theca interna cells. This view was questioned in the case of rats by Parmer et al. (1991), since both small and large luteal cells secrete androgens (Meidan et al., 1990) and express p450 aromatase (McLean and Nelson, 1989). The present findings that both large and small luteal cells are immunoreactive for IGF-I suggest that IGF-I originates from both types of cell within the bovine corpus luteum, and the variable staining intensities between neighbouring cells indicate that IGF-I expression can be up- or downregulated. However, the expression of IGF-I varies greatly among species. Hernandez et al. (1992) found that in women, IGF-I was expressed in theca cells of follicles but not in granulosa cells; whereas Spicer et al. (1993) showed that bovine granulosa cells produce IGF-I in vitro and contain mRNA for IGF-I.

Our results for IGF-II confirm and extend the findings of Hammond et al. (1991) and Hernandez et al. (1990a). These authors found that IGF-II transcripts were specific to thecainterstitial tissue. As reported for pigs by Hammond et al. (1991) and for rats by Adashi et al. (1988b), we could not detect immunoreactive IGF-II in the granulosa layer of antral and preovulatory follicles of cows (unpublished observations). As in other species, bovine luteal tissue is made up of several cell types. In addition to luteal cells, fibroblasts, smooth muscle cells and, to a larger extent, vascular cells (endothelial cells and pericytes) are also present. A surprising result of our study was the restriction of intense IGF-II immunoreactivity to the pericytes of capillaries and to the perivascular fibroblasts of larger vessels. This specific cellular localization can be observed over the whole lifespan of the cyclic corpus luteum indicating a highly compartmentalized IGF-I and IGF-II localization in bovine ovaries, similar to that observed in pigs (Hammond et al., 1991) and rats (Adashi et al., 1988b).

The functional significance of the relatively limited amount of IGF-II immunoreactivity, along with its restriction to mesenchymal cells, is difficult to interpret, as little is known about the role of IGF-II during the lifespan of the corpus luteum. Sauerwein et al. (1992) showed that in luteal tissue IGF-II was the most stimulative for progesterone release during the late luteal phase under conditions in vitro. The authors assumed that this effect would be mediated via the type I receptor. However, the strong immunoreactivity present in particular cell types associated with blood vessels (particularly pericytes) supports the supposition that IGF-II may play an autocrine or paracrine role in coordinating angiogenetic processes during the development of the corpus luteum. Apart from the potent action of other growth factors, for example basic fibroblast growth factor (Neufeld et al., 1987; Gospodarowicz et al., 1985) and vascular endothelial growth factor (Phillips et al., 1990) in ovarian angiogenic processes, the number and localization of pericytes is well established as an important factor in the modulation of endothelial migration and proliferation (Orlidge and D'Amore, 1987; Antonelli-Orlidge et al., 1989; Sato and Rifkin, 1989). It is, for example, considered that a reduced number of pericytes stimulates endothelial mitosis and that the growth status of a particular capillary bed is governed by a balance between endothelial cells and pericytes (AntonelliOrlidge et al., 1989). A considerable number of IGF-II-positive pericytes associated with states of lower endothelial cell turnover (mid- and late luteal phase) were found in the study reported here. Conversely, only single IGF-II-positive pericytes were detected during periods of intense blood vessel formation (early luteal phase). This observation and the ability of pericytes to produce IGF-II in considerable quantity (Cotterill et al., 1991) indicates that IGF-II acts as an autocrine growth factor, affecting the proliferation and differentiation of pericytes, and thereby, acts as a local regulatory growth factor with regard to angiogenetic processes during the ovarian cycle.

This work was supported in part by the Deutsche Forschungsgemeinschaft and Ministry for Science and Technology (01KY 9104). The skilled technical assistance of $\mathrm{M}$. Bergerson and G. Rußmeier and the supply of recombinant human IGF-I and IGF-II by Ciba Geigy, Basle (Dr Müller) was greatly appreciated.

\section{References}

Adashi EY, Resnick CE, D'Ercole AJ, Svoboda ME and Van Wyk JJ (1985a) Insulin-like growth factors as intraovarian regulators of granulosa cell growth and function Endocrine Reviews 6 400-412

Adashi EY, Resnick CE, Brodie AMH, Svoboda ME and Van Wyk JJ (1985b) Somatomedin-C-mediated potentiation of follicle stimulating hormoneinduced aromatase activity of cultured rat granulosa cells Endocrinology 117 $2313-2320$

Adashi EY, Resnick CE, Svoboda ME and Van Wyk JJ (1988a) Characterization and regulation of a specific cell membrane receptor for somatomedin-Cl insulin-like growth factor I in cultured rat granulosa cells Endocrinology 122 194-201

Adashi EY, Resnick CE, Hernandez ER, May JV, Knecht M, Svoboda ME and Van Wyk JJ (1988b) Insulin-like growth factor-I as an amplifier of folliclestimulating hormone action: studies on mechanism(s) and site(s) of action in cultured rat granulosa cells Endocrinology 122 1583-1591

Adashi EY, Resnick CE and Rosenfeld RG (1990) Insulin-like growth factor-I 
(IGF-I) and IGF-II hormonal action in cultured rat granulosa cells: mediation via type I but not type II IGF receptors Endocrinology 126 216-222

Alila HW and Hansel W (1984) Origin of different cell types in the bovine corpus luteum as characterized by specific monoclonal antibodies Biology of Reproduction 31 1015-1025

Antonelli-Orlidge A, Saunders KB, Smith SR and D'Amore PA (1989) An activated form of transforming growth factor $\beta$ is produced by cocultures of endothelial cells and pericytes Proceedings National Academy of Sciences USA $864544-4548$

Baranao JLS and Hammond JM (1984) Comparative effects of insulin and insulin-like growth factors on DNA synthesis and differentiation of porcine granulosa cells Biochemical and Biophysical Research Communications 124 $484-490$

Cotterill AM, Holly JMP, Davies SC, Coulson VJ, Price PA and Wass JAH (1991) The insulin-like growth factors and their binding proteins in a case of non-islet-cell tumour-associated hypoglycaemia Joumal of Endocrinology 131 303-311

Davoren JB, Kasson BG, Li CH and Hsueh AJW (1986) Specific insulin-like growth factor (IGF) I- and II-binding sites on rat granulosa cells: relation to IGF action Endocrinology 119 2155-2162

Einspanier R, Miyamoto A, Schams D, Müller M and Brem G (1990) Tissue concentration, mRNA expression and stimulation of IGF-I in luteal tissue during the oestrous cycle and pregnancy of cows Journal of Reproduction and Fertility $90 \quad 439-445$

Erickson GF, Magoffin DA, Cragun JR and Chang RJ (1990) The effects of insulin and insulin-like growth factors-I and -II on estradiol production by granulosa cells of polycystic ovaries Joumal of Clinical Endocrinology and Metabolism 70 894-902

Gospodarowicz D, Cheng J, Lui GM, Baird A, Esch F and Bohlen P (1985) Corpus luteum angiogenic factor is related to fibroblast growth factor Endocrinology 117 2383-2391

Hammond JM and English HF (1987) Regulation of deoxyribonucleic acid synthesis in cultured porcine granulosa cells by growth factors and hormones Endocrinology 120 1039-1046

Hammond JM, Baranao JLS, Skaleris D, Knight AB, Romanus JA and Rechler MM (1985) Production of insulin-like growth factors by ovarian granulosa cells Endocrinology $1172553-2555$

Hammond JM, Mondschein JS, Samaras SE and Canning SF (1991) The ovarian insulin-like growth factors: a local amplification mechanism for steroidogenesis and hormone action Journal of Steroid Biochemistry and Molecular Biology $40411-416$

Hernandez ER, Roberts CT, LeRoith D and Adashi EY (1990a) Rat ovarian insulin-like growth factor I (IGF-I) gene expression is granulosa-selective: 5 '-untranslated mRNA variant representation and hormonal regulation Endocrinology $125 \quad 572-574$

Hernandez ER, Roberts CT, Hurwitz A, LeRoith D and Adashi EY (1990b) Rat ovarian insulin-like growth factor II gene expression is theca-interstitial cell-exclusive: hormonal regulation and receptor distribution Endocrinology 127 3249-3251

Hernandez ER, Hurwitz A, Vera A, Pellicer A, Adashi EY, LeRoith D and Roberts CT, Jr (1992) Expression of the genes encoding the insulin-like growth factors and their receptors in the human ovary Journal of Clinical Endocrinology and Metabolism 74 419-425

Höflinger H (1948) Das Ovar des Rindes in den verschiedenen Lebensperioden unter besonderer Berücksichtigung seiner funktionellen Feinstruktur Acta Anatomica Supplement 5

Holtorf AP, Furuya K, Ivell R and McArdle CA (1989) Oxytocin production and oxytocin messenger ribonucleic acid levels in bovine granulosa cells are regulated by insulin and insulin-like growth factor-I: dependence on developmental status of the ovarian follicle Endocrinology 125 2612-2620

Hsueh AJW, Adashi EY, Jones PBC and Welsh TH (1984) Hormonal regulation of the differentiation of cultured ovarian granulosa cells Endocrine Reviews 5 $76-84$

McArdle CA and Holtorf AP (1989) Oxytocin and progesterone release from bovine corpus luteal cells in culture: effects of insulin-like growth factor I, insulin, and prostaglandins Endocrinology 124 1278-1286
McLean MP and Nelson S (1989) Differential capacity for cholesterol transport (SCP2) and processing $\left(\mathrm{P}^{4} \mathrm{SO}_{\text {scc }}\right)$ in large and small rat luteal cells $22 \mathrm{nd}$ Annual Meeting of the Society for the Study of Reproduction Columbia MO, p 58 Ed. DJ Dierschke. Society for the Study of Reproduction, Missouri

May JV, Frost JP and Schomberg, DW (1988) Differential effects of epidermal growth factor, somatomedin-C/insulin-like growth factor I, and transforming growth factor-b on porcine granulosa cell deoxyribonucleic acid synthesis and cell proliferation Endocrinology 123 168-179

Meidan R, Girsh E, Blum O and Aberdam E (1990) In Vitro differentiation of bovine theca and granulosa cells into small and large luteal-like cells: morphological and functional characteristics Biology of Reproduction $\mathbf{4 3}$ 913-921

Monniaux D and Pisselet C (1992) Control of proliferation and differentiation of ovine granulosa cells by insulin-like growth factor-I and follicle-stimulating hormone in vitro Biology of Reproduction 46 109-119

Neufeld G, Ferrara N, Schweigerer L, Mitchell R and Gospodarowicz D (1987) Bovine granulosa cells produce basic fibroblast growth factor Endocrinology $121597-603$

Oliver JE, Aitman TJ, Povell JF, Wilson CA and Clayton RN (1989) IGF-I gene expression in the rat ovary is confirmed to the granulosa cells of developing follicles Endocrinology 124 2671-2679

Olsson JH, Carlsson B and Hillensjö T (1990) Effect of insulin-like growth factor I on deoxyribonucleic acid synthesis in cultured human granulosa cells Fertility and Sterility $54 \quad$ 1052-1057

Orlidge A and D'Amore PA (1987) Inhibition of capillary endothelial cell growth by pericytes and smooth muscle cells Journal of Cell Biology 105 $1455-1462$

O'Shea JD (1987) Heterogeneous cell types in the corpus luteum of sheep, goats and cattle Joumal of Reproduction and Fertility Supplement 34 71-85

Parmer TG, Roberts T, Jr, LeRoith D, Adashi EY, Khan I, Solan N, Nelson S, Zilberstein M and Gibori G (1991) Expression, action and steroidal regulation of insulin-like growth factor-I (IGF-I) and IGF-I receptor in the rat corpus luteum: their differential role in the two cell populations forming the corpus luteum Endocrinology 129 2924-2932

Phillips HS, Hains J, Leung DW and Ferrara N (1990) Vascular endothelial growth factor is expressed in rat corpus luteum Endocrinology $127965-967$

Sato Y and Rifkin DB (1989) Inhibition of endothelial cell movement by pericytes and smooth muscle cells: activation of a latent transforming growth factor- $\beta$-1 like molecule by plasmin during co-culture Joumal of Cell Biology 109 309-315

Sauerwein H, Miyamoto A, Günther J, Meyer HHD and Schams D (1992) Binding and action of insulin-like growth factors and insulin in bovine luteal tissue during the oestrous cycle Joumal of Reproduction and Fertility 96 103-115

Schams D (1987) Luteal peptides and intercellular communication Journal of Reproduction and Fertility Supplement 34 87-99

Schams D, Koll R and Li CH (1988) Insulin-like growth factor I stimulates oxytocin and progesterone production by bovine granulosa cells in culture Journal of Endocrinology 116 97-100

Snedecor and Cochran (1982) Statistical Methods. Iowa State University Press, Ames

Steinkampf MP, Mendelson CR and Simpson ER (1988) Effects of epidermal growth factor and insulin-like growth factor I on the levels of mRNA encoding aromatase cytochrome P-450 of human ovarian granulosa cells Molecular Cell Endocrinology 59 93-99

Spicer LJ, Alpisar E and Echternkamp SE (1993) Effects of insulin, insulin-like growth factor I, and gonadotropins on bovine granulosa cell proliferation, progesterone production, estradiol production and (or) insulin-like growth factor I production in vitro Journal of Animal Science 71 1232-1241

Veldhuis JD and Demers M (1985) A role for somatomedin C as a differentiating hormone and amplifier of hormone action on ovarian cells: studies with synthetically pure human somatomedin $\mathrm{C}$ and swine granulosa cells Biochemical and Biophysical Research Communications 130 234-240

Veldhuis JD, Rodgers RJ, Dee A and Simpson ER (1986) The insulin-like growth factor, somatomedin $\mathrm{C}$, induces the synthesis of cholesterol side-chain cleavage cytochrome P-450 and adrenodoxin in ovarian cells Journal of Biological Chemistry 261 2499-2502 